\title{
Association of Hyperuricemia and Raised Atherogenic Index of Plasma with Hypertension
} \author{
Sumona Biswas ${ }^{6}$ \\ ${ }^{1}$ Assistant Professor Biochemistry Department, CARe Medical College, Bangladesh \\ ${ }^{2}$ Assistant Professor Biochemistry Department, Bangladesh Medical College, Bangladesh \\ ${ }^{3}$ Department of Cardiology, BSMMU, Bangladesh \\ ${ }^{4}$ Department of Paediatric Cardiology, BSMMU, Bangladesh \\ ${ }^{5}$ Assistant Professor Biochemistry Department, Anwer khan Modern Medical College, Bangladesh \\ ${ }^{6}$ Lecturer Forensic Medicine and Toxicology Department, Shaheed Suhrawardy Medical College, Bangladesh
}

Rumana Ahmed*1, Sadia Khanduker ${ }^{2}$, Sheikh Foyez Ahmed ${ }^{3}$, Elora Sharmin ${ }^{4}$, Farhana Khondokar ${ }^{5}$ and $^{*}$

Submission: July 06, 2017; Published: July 10, 2017

*Corresponding author: Rumana Ahmed, Assistant Professor, CARe Medical College, 2/1-A Iqbal Road, Mohammadpur, Dhaka, Bangladesh, Tel: +88-01711976715; Email: rumana.tumpa@gmail.com

Abstract

Background: Among the non-communicable disease, CVD is one of the major reasons of mortality all over the world. Hypertension is an important contributor to cardiovascular disease, stroke and kidney disease.

Objective: To evaluate the association of serum uric acid and atherogenic index of plasma with hypertension.

Method: A total of 100 individuals were selected as study subjects based on predefined enrollment criteria. Among them 50 diagnosed cases of hypertension were selected as cases and 50 normotensive healthy individuals as controls. Serum uric acid and serum lipid profile were measured in all study subjects. Atherogenic index of plasma was calculated by the formula log (TG/HDL-C).

Result: The study population mostly belonged to 36 to 45 years of age group. The mean age of hypertensive patients was $40.78 \pm 4.00$ years and that of controls was $39.58 \pm 4.12$ years. The study found that the mean levels of serum TG $(205.24 \pm 56.74 \mathrm{mg} / \mathrm{dl})$ in hypertensive patients were significantly higher than those of controls whereas mean level of HDL-C $(42.10 \pm 12.27 \mathrm{mg} / \mathrm{dl})$ in hypertensive patients were lower than those of controls. The mean AIP in the hypertensive patients was $(0.68 \pm 0.19)$ significantly higher $(\mathrm{p}<0.001)$ than that of controls $(0.43 \pm 0.22)$. In the study $70 \%$ of the hypertensive subjects were found to be hyperurecemic whereas $08 \%$ of the normotensive subjects were hyperurecemic which was statistically significant. The hypertensive subjects showed a positive significant $(r=0.437 \mathrm{p}=0.002)$ correlation between AIP and SUA.

Conclusion: From the study it is evident that hyperuricemia and high AIP are associated with hypertension.

Abbreviations: CVD: Cardiovascular Disease; NCD: Non-Communicable Diseases; WHO: World Health Organization; BSMMU: Bangabandhu Sheikh Mujib Medical University; SSMC: Sir Salimullah Medical College; TG: Triglyceride; HTN: Hypertension; CHD: Coronary Heart Disease; HDL-C: High Density Lipoprotein-Cholesterol; AIP: Atherogenic Index of Plasma; DBP: Diastolic Blood Pressure SBP: Systolic Blood Pressure; SPSS: Statistical Package for Social Science

\section{Introduction}

Cardiovascular disease (CVD) is a major cause of global mortality and is a serious health problem in developed as well as in developing countries. In Bangladesh, deaths due to noncommunicable diseases (NCD), especially chronic diseases are increasing at an alarming rate. Among them CVD, cancers, chronic respiratory diseases, and diabetes are responsible for an increasing number of deaths [1]. CVD has become a significant burden on the health care service in Bangladesh. World Health Organization (WHO) reported that $27 \%$ of total deaths in Bangladesh were due to CVD [2]. CVD is the highest among all causes of death followed by diseases of the respiratory system [3].

Several risk factors have been identified for the development of CVD such as smoking, high blood pressure, high blood 


\section{Anatomy Physiology \& biochemistry international journal (APBIJ)}

cholesterol, serum uric acid (SUA) [4], diabetes mellitus [5] and family history of CVD [6]. Among various risk factors hypertension (HTN) is identified as one of the modifiable risk factors for cardiovascular and kidney diseases [7]. HTN increases the risk for a variety of cardiovascular diseases including stroke, coronary artery disease, heart failure and peripheral vascular disease [8]. Among individuals aged 40 to 90 years, each 20/10 $\mathrm{mmHg}$ rise in blood pressure doubles the risk of fatal coronary events [9]. HTN accounts for an estimated 54 percent of all strokes and 47 percent of all ischemic heart diseases globally [10].

Atherogenic Index of Plasma (AIP) is used to assess the cardiovascular risk. People with high AIP have a higher risk for coronary heart disease (CHD) than those with low AIP. Triglyceride (TG) and high density lipoprotein-cholesterol (HDL-C) in AIP reflect the balance between the atherogenic and anti-atherogenic lipoproteins respectively. It has been suggested that AIP values of -0.3 to 0.1 are associated with low, $>0.1$ to 0.24 with medium and above 0.24 with high CVD risk [11].

Uric acid is another important risk factor for CVD. The increase in the SUA level was identified as an independent factor for the cardiovascular death [12].Uric acid is a major factor for the development of CVD in hypertensive patients $[4,13]$. It has been reported that $25-40 \%$ of patients with untreated HTN have high SUA levels. In the Framingham Heart Study, each increase in SUA by $1.3 \mathrm{mg} / \mathrm{dl}$ was found to be associated with the development of HTN with an odd ratio of 1.17 [14]. SUA has been shown to aggravate both dyslipidemia and hyperglycaemia $[13,15]$. A study conducted in India, showed that the SUA level is positively associated with AIP [16]. The aim of this study is to see the correlation between SUA and AIP with HTN.

\section{Method}

This case-control analytical study was carried out in the Department of Biochemistry, Sir Salimullah Medical College (SSMC), Dhaka during the period of July 2012 to May 2014. Fifty hypertensive patients of any sexes and above 30 years old patients of out-door at Bangabandhu Sheikh Mujib Medical University (BSMMU) and SSMC were included in the study as cases. Fifty age and sex matched non-hypertensive subjects were also taken from medical or paramedical staff, attendants of patients, persons coming to hospital for fitness purpose and outdoor patients of minor illness.

Patients with diabetes mellitus, thyroid disorder, heart disease, renal impairment, liver disease were excluded from the study population. Patients taking drug therapy such as thiazide and loop diuretics, cytotoxic drug, antitubercular drug, low dose aspirin, antioxidant as well as taking medications targeted to reduce uric acid level and lipid lowering drug also excluded from study. Smoker and alcohol abused were also excluded.
A complete physical and relevant clinical examination was performed. Blood pressure was measured in a sitting position after resting for at least 15 minutes. Average of two measurements at 15 minute interval was taken. Hypertension was defined as a Diastolic Blood Pressure (DBP) $\geq 90 \mathrm{mmHg}$ and or Systolic Blood Pressure (SBP) $\geq 140 \mathrm{mmHg}$. Laboratory investigation of serum TG, HDL-C and uric acid were done. AIP of all study subjects was calculated. Hyperuricemia was defined as serum uric acid concentration $>7 \mathrm{mg} / \mathrm{dl}$ in male and $>6 \mathrm{mg}$ / $\mathrm{dl}$ in female. Collected data were checked, edited, processed and statistical analysis were performed using Statistical Package for Social Science (SPSS) version 12.0.

\section{Results}

In the hypertensive group, 26 (52.0\%) were male and 24 (48.0\%) were female and in the control group 29 (58.0\%) were male and $21(42.0 \%)$ were female. The mean age of hypertensive patients was $40.78 \pm 4.00$ years and that of controls was $39.58 \pm$ 4.12 years (Table 1 ). The mean systolic BP were $145 \pm 10$ $\mathrm{mmHg}$ and $115 \pm 9 \mathrm{mmHg}$ in hypertensive and control subjects respectively; the mean diastolic BP were $87 \pm 6 \mathrm{mmHg}$ and $77 \pm 6 \mathrm{mmHg}$ in hypertensive and control subjects respectively. Both systolic and diastolic BP was significantly higher in the hypertensive group than that of control group (Table 2). Serum TG was significantly higher compared with those of controls. Serum HDL-C was lower in the hypertensive subjects compared with that of controls. AIP in the hypertensive patients was significantly higher when compared with that of controls (Table 3). Serum uric acid level in hypertensive patients was found to be significantly higher when compared with that of controls. $70 \%$ of the hypertensive subjects were hyperurecemic whereas $08 \%$ of the normotensive subjects were hyperurecemic which was statistically significant (Table 4). The study showed a positive significant correlation between AIP and SUA ( $r=0.437, p=0.002)$ in hypertensive subjects (Figure 1).

Table 1: Distribution of study subject according to sex.

\begin{tabular}{|c|c|c|c|}
\hline \multirow{2}{*}{ Sex } & \multicolumn{2}{|c|}{ Group } & \multirow{2}{*}{ p value } \\
\cline { 2 - 3 } & $\begin{array}{c}\text { Hypertensive } \\
\text { patients }\end{array}$ & Controls & \\
\hline Male n (\%) & $26(52.0)$ & $29(58.0)$ & $0.546^{*}$ \\
\hline Female n (\%) & $24(48.0)$ & $21(42.0)$ & \\
\hline Age (Mean \pm SD) & $40.78 \pm 4.00$ & $39.58 \pm 4.12$ & $0.142 \#$ \\
\hline
\end{tabular}

Table 2: Comparison of blood pressure between cases and controls.

\begin{tabular}{|r|c|c|c|}
\hline \multirow{2}{*}{ Blood pressure } & \multicolumn{2}{|c|}{ Group } & \multirow{2}{*}{ p value } \\
\cline { 2 - 3 } & $\begin{array}{c}\text { Hypertensive } \\
\text { patients }\end{array}$ & Control & \\
\hline Systolic BP (mm Hg) & $145 \pm 10$ & $115 \pm 9$ & 0.001 \\
\hline Diastolic BP (mm Hg) & $87 \pm 6$ & $77 \pm 6$ & 0.001 \\
\hline
\end{tabular}




\section{Anatomy Physiology \& biochemistry international journal (APBIJ)}

Table 3: Comparison of Atherogenic index of plasma between cases and controls.

\begin{tabular}{|c|c|c|c|}
\hline $\begin{array}{c}\text { Biochemical } \\
\text { finding }\end{array}$ & $\begin{array}{c}\text { Hypertensive } \\
\text { patients (n=50) }\end{array}$ & $\begin{array}{c}\text { Controls } \\
(\mathbf{n = 5 0})\end{array}$ & P value \\
\hline $\mathrm{TG}(\mathrm{mg} / \mathrm{dl})$ & $205 \pm 56.74$ & $136.84 \pm 52.81$ & 0.001 \\
\hline $\mathrm{HDL}-\mathrm{C}(\mathrm{mg} / \mathrm{dl})$ & $42.10 \pm 12.27$ & $48.10 \pm 12.43$ & 0.017 \\
\hline $\mathrm{AIP}$ & $0.68 \pm 0.19$ & $0.43 \pm 0.22$ & 0.001 \\
\hline
\end{tabular}

Table 4: Distribution of the study patients according to Hyperuricemia.

\begin{tabular}{|c|c|c|c|}
\hline \multirow{2}{*}{ Hyperuricemia } & \multicolumn{2}{|c|}{ Group } & \multirow{2}{*}{ p value } \\
\cline { 2 - 3 } & $\begin{array}{c}\text { Hypertensive } \\
\text { patients }\end{array}$ & Control & \\
\hline Yes & $35(70.0)$ & $4(8.0)$ & 0.001 \\
\hline No & $15(30.0)$ & $46(92.0)$ & \\
\hline Total & $50(100.0)$ & $50(100.0)$ & \\
\hline
\end{tabular}

Odds Ratio is $26.83(8.18-87.96)$

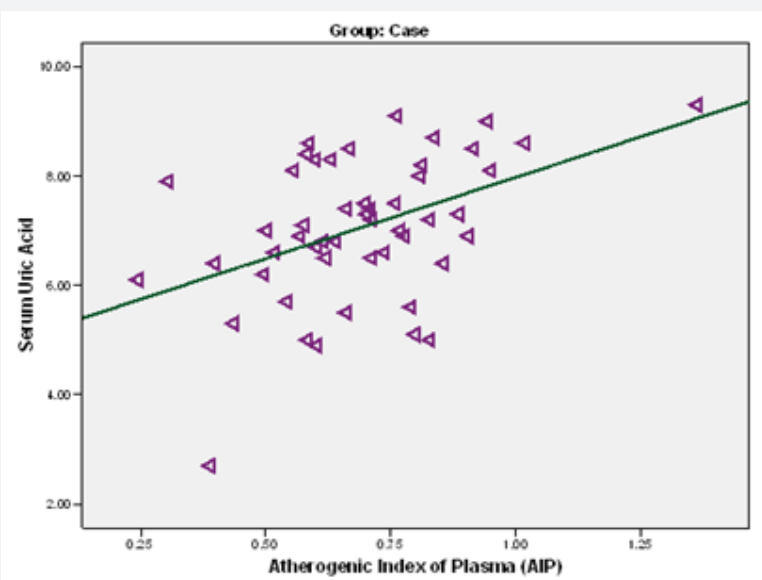

Figure 1: Correlation between atherogenic index of plasma and serum uric acid in cases. Pearson correlation, $r$ is 0.437 with a $p$ value of 0.002 .

\section{Discussion}

The present study shows that serum TG was significantly higher in hypertensive patients than those of normotensive controls. Shah et al. [17] revealed similar findings of elevated serum TG when he compared TG, TC and LDL-C between the hypertensive subjects and controls. Similar observation was also reported in the study carried out by Sarkar et al. [18] Present study showed that serum HDL-C was significantly lower $(p=0.017)$ in cases than controls and this finding agree with the finding of the study done by Al-Baldawi [19]. The multiple risk factor intervention trial in USA showed that for each decrease in HDL cholesterol of $1 \mathrm{mg} / \mathrm{dL}(0.03 \mathrm{mmol} / \mathrm{L})$ was associated with an increase in the risk of CHD of $2 \%$ in men and $3 \%$ in women [20].

In this study, $70 \%$ had elevated level of SUA in cases. Garrick et al. [21] in their study observed that $31 \%$ of their study patients with hypertension had hyperuricemia.
In some studies hyperuricemia was found to be present in 40 to $60 \%$ of subjects with untreated hypertension $[22,23]$. Present study showed a close association of hyperuricemia with hypertension with an Odd Ratio of 26.83. A positive association between hypertension and serum uric acid has been shown by some other authors [24,25]. The present study observed significantly higher AIP ratio in cases than that of controls $(p=0.001)$. Calin [26] in their study observed moderately increased AIP in hypertensive patients. Marwan et al. [27] also found that atherogenic index to be higher in hypertensive than normotensive subjects.

The hypertensive subjects showed a positive significant $r=$ $0.437(\mathrm{p}=0.002)$ correlation between AIP and SUA. Our findings that SUA is positively associated with AIP can be explained by the following facts: (a) elevated SUA has been well linked to increase in TG in various populations $[28,29]$ and (b) the negative association between SUA and HDL-C has also been documented [30].

\section{Conclusion}

From this study it can be concluded than hyperuricemia and raised atherogenic index of plasma is associated with hypertension.

\section{References}

1. Directorate General of Health Services (2011) Strategic plan for surveillance and prevention of non communicable diseases in Bangladesh 2011-2015. Dhaka.

2. WHO NCD Country Profiles. (2011)Bangladesh. NCD Country Profiles. WHO.

3. (2012) Director General Health Services, Health Bulletin. Dhaka, MIS, DGHS. 88-101.

4. Alderman MH (2001) Serum uric acid as a cardiovascular risk factor for heart disease. Current hypertension reports 3(3): 184-189.

5. Gordon T, Kannel WB (1982) Multiple risk functions for predicting coronary heart disease: the concept, accuracy, and application. American Heart Journal 103(6): 1031-1039.

6. Wilson PW, D'Agostino RB, Levy D, Belanger AM, Silbershatz H, et al. (1998) Prediction of coronary heart disease using risk factor categories. Circulation 97(18): 1837-1847.

7. Whelton PK, He J, Muntner P (2004) Prevalence, awareness, treatment and control of hypertension in North America, North Africa and Asia. Journal of human hypertension 18(8): 545-551.

8. Lloyd-Jones D, Adams RJ, Brown TM (2010) Executive summary: heart disease and stroke statistics-2010 update: a report from the American Heart Association. Circulation 121(7): 948-954.

9. Lewington S, Clarke R, Qizilbash N, Peto R, Collins R (2002) Age-specific relevance of usual blood pressure to vascular mortality: a metaanalysis of individual data for one million adults in 61 prospective studies. Lancet 360(9349): 1903-1913.

10. Lawes CM, Vander Hoorn S, Rodgers A (2008) Global burden of bloodpressure-related disease 2001. The Lancet 371(9623): 1513-1518.

11. Dobiášová M, Frohlich J (2001) The plasma parameter log (TG/HDL-C) as an atherogenic index: correlation with lipoprotein particle size and 


\section{Anatomy Physiology \& biochemistry international journal (APBIJ)}

esterification rate inapoB-lipoprotein-depleted plasma (FER HDL). Clinical biochemistry 34(7): 583-588.

12. Liese AD, Hense HW, Löwel H, Döring A, Tietze M, et al. (1999) Association of Serum Uric Acid with All-Cause and Cardiovascular Disease Mortality and Incident Myocardial Infarction in the MONICA Augsburg Cohort. Epidemiology 10(4): 391-397.

13. Feig DI, Johnson RJ (2003) Hyperuricemia in childhood primary hypertension. Hypertension 42(3): 247-252.

14. Sundström J, Sullivan L, D’Agostino RB, Levy D, Kannel WB, et al. (2005) Relations of serum uric acid to longitudinal blood pressure tracking and hypertension incidence. Hypertension 45(1): 28-33.

15. Kačkov S, Šimundić AM, Nikolac N, Bilušić M (2011) The association of uric acid with glucose and lipids in general population: Croatian crosssectional study. Collegium antropologicum 35(4): 1055-1059.

16. Baliarsingh S, Sharma N, Mukherjee R (2013) Serum uric acid: Marker for atherosclerosis as it is positively associated with "atherogenic index of plasma". Archives of Physiology and Biochemistry 119(1): 27-31.

17. Saha MS, Sana NK, Shaha RK (2006) Serum lipid profile of hypertensive patients in the northern region of Bangladesh. Journal of Bio-Science 14: 93-98.

18. Sarkar D, Latif SA, Uddin MM, Aich J, Sutradhar SR, et al. (2007) Studies on serum lipid profile in hypertensive patient. Mymensingh medical journal 16(1): 70-76.

19. Al-Baldawi AT (2006) Evaluation of Amino acid Homocysteine in Hypertensive Patients. The Iraqi Postgraduate Medical Journal. 5: 151 154

20. Gordon DJ, Probstfield JL, Garrison RJ, Neaton JD, Castelli WP (1989) High-density lipoprotein cholesterol and cardiovascular disease. Four prospective American studies. Circulation 79(1): 8-15.

21. Garrick R, Bauer GE, Ewan CE, Neale FC (2008) Serum Uric Acid in Normal and Hypertensive Australian Subjects: From a Continuing
Epidemiological Survey on Hypertension Commenced in 1955. Australian and New Zealand Journal of Medicine 2(4): 351-356.

22. Bulpitt CJ (1975) Serum uric acid in hypertensive patients. British heart journal 37(12): 1210-1215.

23. Kinsey D, Smithwick R, Walther R, Whitelaw G, Sise H (1961) Incidence of hyperuricemia in 400 hypertensivepatients. Circulation 24(4): 972.

24. Nguedia AJ, Nsagha DS, Njunda AL, Waidim Y, Lemuh DN, et al. (2014) The Relationship between Uric Acid and Hypertension in Adults in Fako Division, SW Region Cameroon Nutrition and Food Sciences 4(1): $1-4$.

25. Teng F, Zhu R, Zou C, Xue Y, Yang M, et al. (2011) Interaction between serum uric acid and triglycerides in relation to blood pressure. Journal of Human Hypertension 25(11): 686-691.

26. Calin P, Maria P (2012) Atherogenic risk quantification by using the atherogenic index of plasma (AIP) and cardiovascular risk calculator in hypertensive patients. Medical Connections 8(1): 29-36.

27. Marwan AN, Ismail H, Warda L (2010) Subtype of hypertension is evidence for preclinical atherosclerosis. Neurosciences 15(2): 79-83.

28. Li Y, Stamler J, Xiao Z, Folsom A, Tao S, et al. (1997) Serum uric acid and its correlates in Chinese adult populations, urban and rural, of Beijing. The PRC-USA Collaborative Study in Cardiovascular and Cardiopulmonary Epidemiology. Internation Journal of Epidemiology 26(2): 288-296.

29. Conen D, Wietlisbach V, Bovet P, Shamlaye C, Riesen W, et al. (2004) Prevalence of hyperuricemia and relation of serum uric acid with cardiovascular risk factors in a developing country. BMC public health. 4(2): 9-12.

30. Ishizaka N, Ishizaka Y, Toda E, Nagai R, Yamakado M (2005) Association between serum uric acid, metabolic syndrome, and carotid atherosclerosis in Japanese individuals. Arteriosclerosis, thrombosis, and vascular biology 25(5): 1038-1044.

Your next submission with Juniper Publishers will reach you the below assets

- Quality Editorial service

- Swift Peer Review

- Reprints availability

- E-prints Service

- Manuscript Podcast for convenient understanding

- Global attainment for your research

- Manuscript accessibility in different formats ( Pdf, E-pub, Full Text, Audio)

- Unceasing customer service

Track the below URL for one-step submission https://juniperpublishers.com/online-submission.php 